\title{
SRT1720 retards renal fibrosis via inhibition of HIF1A/GLUT1 in diabetic nephropathy
}

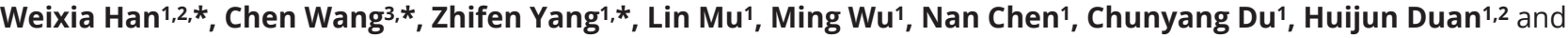 \\ Yonghong Shi1,2
}

1Department of Pathology, Hebei Medical University, Shijiazhuang, China

2Hebei Key Laboratory of Kidney Diseases, Shijiazhuang, China

${ }^{3}$ Department of Pathology, Second Hospital, Shanxi Medical University, Taiyuan, China

Correspondence should be addressed to Y Shi: yonghongshi@163.com

*(W Han, C Wang and Z Yang contributed equally to this work)

\begin{abstract}
Renal fibrosis is the major pathological characteristic of diabetic nephropathy (DN). Reportedly, increased SIRT1 expression played a renal protective role in animal models of DN. This study was designed to elucidate the molecular mechanisms underlying the protective effects of SRT1720, an SIRT1 activator, against diabetes-induced renal fibrosis. Type 2 diabetic mice (db/db) were treated with SRT1720 (50 mg/kg/day) by gavage for 10 weeks. Renal proximal tubular epithelial cells (HK-2 cells) were treated with high glucose $(\mathrm{HG}, 30 \mathrm{mM})$ in the presence or absence of SRT1720 (2.5 $\mu \mathrm{M})$ for $48 \mathrm{~h}$. We observed that impaired SIRT1 expression and activity were restored by SRT1720 administration in $\mathrm{db} / \mathrm{db}$ mice as well as in HG-treated HK-2 cells. Moreover, SRT1720 administration improved the renal function, attenuated glomerular hypertrophy, mesangial expansion, glomerulosclerosis and interstitial fibrosis and inhibited TGFB1 and CTGF expressions and nuclear factor $\kappa B(N F-K B)$ activation in $\mathrm{db} / \mathrm{db}$ mice. Similarly, HG-induced epithelial-to-mesenchymal transformation (EMT) and collagen IV and fibronectin expressions were inhibited in SRT1720-treated HK-2 cells. Mechanistic studies demonstrated that SRT1720 suppressed HIF1A, GLUT1 and SNAIL expressions both in vivo and in vitro. Furthermore, HIF1A or GLUT1 knockdown effectively abrogated HG-induced EMT and collagen IV and fibronectin expressions in HK-2 cells. These findings suggest that SRT1720 prevented diabetes-induced renal fibrosis via the SIRT1/HIF1A/GLUT1/SNAIL pathway.
\end{abstract}

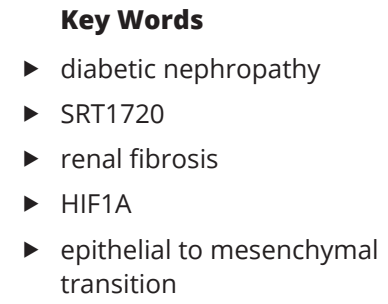

Journal of Endocrinology (2019) 241, 85-98

\section{Introduction}

Diabetic nephropathy (DN) is a microvascular complication of diabetes mellitus, accounting for almost $50 \%$ of all end-stage renal disease cases. Renal fibrosis is a major characteristic of DN and an important predictor of renal dysfunction (Gilbert \& Cooper 1999). However, the molecular mechanisms by which diabetes induced renal fibrosis remain largely unknown.
Silent mating type information regulation 2 homolog 1 (SIRT1) is a member of the Sirtuin family (SIRT 1-7). Reportedly, SIRT1 alleviated diabetes by preventing hepatic insulin resistance and enhancing pancreatic insulin secretion (Moynihan et al. 2005, Wang et al. 2011). In addition, protective effects of SIRT1 on renal injuries caused by ischaemia/reperfusion (I/R), unilateral ureter 
obstruction (UUO) or aldosterone have been reported (Li et al. 2010, Yuan et al. 2012, Fan et al. 2013). Resveratrol, an SIRT1 activator, prevented $\mathrm{DN}$ in $\mathrm{db} / \mathrm{db}$ mice via SIRT1-PGC1A signalling (Kim et al. 2013). Moreover, podocyte-specific Sirt1 overexpression attenuated diabetes-induced podocyte loss and reduced oxidative stress in the glomeruli of OVE26 mice (Hong et al. 2018). Similarly, heterogeneous nuclear ribonucleoprotein F protected kidneys from oxidative stress and nephropathy by stimulation of SIRT1 expression in $\mathrm{db} / \mathrm{db}$ mice (Lo et al. 2017). Therefore, stimulation of SIRT1 expression is a therapeutic target to prevent the progression of renal injury in diabetes.

SRT1720 is a small molecule that dramatically increases SIRT1 deacetylase activity (Milne et al. 2007). SRT1720 induced significant renal SIRT1 mRNA and protein expressions in cholic acid-fed mice (Kulkarni et al. 2016) and markedly improved renal tubular pathology and overall renal function in adult mice following I/R (Fan et al. 2013). Our recent study has shown that SRT1720 attenuated renal fibrosis by inhibiting connective tissue growth factor (CTGF) expression and reducing oxidative stress in UUO mice (Ren et al. 2017). However, effects of SRT1720 on DN remain unknown.

Chronic hypoxia has been implicated in the development and progression of DN (Singh et al. 2008). Hypoxia inducible factor 1 alpha (HIF1A) is a key transcriptional regulator of cellular adaptation to hypoxia. HIF1A stimulated expression of various gene products in hypoxia (such as TWIST and SNAIL), promoting renal fibrosis and chronic kidney disease (CKD) progression in certain models (Higgins et al. 2007, Kimura et al. 2008, Sun et al. 2009, Du et al. 2014). Nayak et al. have demonstrated that HIF1A mediated renal fibrosis in type 1 diabetic mice (Nayak et al. 2016). In hypoxia, SIRT1 deacetylated and inactivated HIF1A, inhibiting fibrosis in hypoxic adipose tissue (Li et al. 2016). However, whether SIRT1 alleviates renal fibrosis via HIF1A inhibition remains unknown in DN. Therefore, the aims of the present study were to determine whether SRT1720 exerts a beneficial effect on renal fibrosis in $\mathrm{DN}$ and to explore the underlying signalling pathway.

\section{Materials and methods}

\section{Antibodies and other reagents}

SRT1720 was purchased from BioChemPartner (Shanghai, China). Antibodies against SIRT1, HIF1A, GLUT1, fibronectin, collagen IV, E-cadherin, $\alpha$-SMA, NF-KB p65 and 8-hydroxydeoxyguanosine (8-OHdG) were obtained from Abcam. Antibodies for transforming growth factor beta 1 (TGFB1), NAD(P)H oxidase 4 (NOX4), CTGF, SNAIL, Histone $\mathrm{H} 3$ and $\beta$-actin were purchased from Proteintech (Chicago, USA). Goat anti-rabbit or mouse IgG-HRP secondary antibodies, TRITC-labelled goat anti-rabbit secondary antibody and FITC-labelled goat anti-rabbit or mouse IgG secondary antibodies were purchased from Zhongshan Goldenbridge Biotechnology (Beijing, China). Biochemical parameters in urine and plasma were measured with the reagent kits purchased from BioSino Biotechnology and Science (Beijing, China). PVDF membranes were purchased from Millipore. All culture media were from Gibco-BRL, and the Lipofectamine RNAiMAX was purchased from Invitrogen Life Technologies.

\section{Animals}

Male $\mathrm{C} 57 \mathrm{BL} / \mathrm{KsJ} \mathrm{db} / \mathrm{db}$ mice and littermate control $\mathrm{db} / \mathrm{m}$ mice were obtained from the Nanjing University. All experimental animals were housed under specific pathogen-free conditions with clean sawdust bedding according to the guidelines of the National Institute of Health. The Ethics Committee of Hebei Medical University reviewed and approved all procedures involving mice. At 10 weeks of age, the mice randomly divided the mice into three groups: $\mathrm{db} / \mathrm{m}(n=6), \mathrm{db} / \mathrm{db}(n=6)$ and $\mathrm{db} / \mathrm{db}+\mathrm{SRT} 1720 \quad(n=6)$. The $\mathrm{db} / \mathrm{db}+\mathrm{SRT} 1720$ group received $50 \mathrm{mg} / \mathrm{kg}$ SRT1720 every day by gavage. SRT1720 dose was selected based on a previous publication (Kulkarni et al. 2016). Mice in the control or diabetes groups received the same amount of solvent (30\% PEG400/0.5\% Tween $80 / 5 \%$ propylene glycol). At the age of 20 weeks, animals were killed and the kidneys were harvested for further analysis. Plasma and urinary supernatants were collected and stored at $-80^{\circ} \mathrm{C}$ until further analysis.

\section{Blood and urine chemistry}

At the age of 20 weeks, mice were individually housed in metabolic cages to collect 24-h urine. Blood samples were withdrawn from the retrobulbar venous plexus using a capillary after 12 -h fasting. Plasma and urinary supernatants were measured using reagent kits according to the manufacturer's instructions.

\section{Urine 8-OHdG measurements}

Urine specimens were centrifuged at $220 \boldsymbol{g}$ for $10 \mathrm{~min}$ to remove particulates. We used the supernatants and 
measured 8-OHdG levels using a competitive in vitro enzyme-linked immunosorbent assay kit (Abcam) according to the manufacturer's instructions.

\section{Tissue histology}

The kidneys were fixed in $4 \%$ paraformaldehyde for $48 \mathrm{~h}$, paraffin embedded and cut. The sections were stained with periodic acid-Schiff and Masson's Trichrome staining. A semi-quantitative index was used to evaluate the degree of glomerular mesangial expansion and sclerosis (Zhao et al. 2006).

\section{Human renal biopsies}

Human renal biopsies were collected in the Second Hospital of Shanxi Medical University. The protocol was approved by the Ethical Committees of Shanxi Medical University. A total of 22 kidney biopsies from individual patients in our analyses: 18 samples were collected from patients with type 2 diabetes and biopsy-proven DN and 4 normal human renal tissue samples were obtained from distant portions of kidneys surgically excised because of the presence of localised neoplasms. In the DN group, renal biopsies were performed to exclude the coexistence of other types of kidney disease.

\section{Immunohistochemistry}

After formalin fixation and paraffin embedding, $4 \mu \mathrm{m}$ sections were deparaffinised with xylene and rehydrated by passing them through graded ethanol. Endogenous peroxidase activity was inactivated with $3 \%$ hydrogen peroxide in $100 \%$ methanol for $15 \mathrm{~min}$ after antigen retrieval with heat in $10 \mathrm{mM}$ citrate buffer. Next, $10 \%$ normal goat serum in phosphate-buffered saline (PBS) were added to the sections for $30 \mathrm{~min}$ at room temperature to block nonspecific antibody binding. Then sections were incubated with the following primary antibodies overnight at $4^{\circ} \mathrm{C}$ in PBS: SIRT1, HIF1A, TGFB1, E-cadherin, $\alpha$-SMA, SNAIL, CTGF, NF-KBp65, NOX4 and 8-OHdG. After rinsing in PBS, sections were incubated with biotinylated secondary antibody and horseradish peroxidase-conjugated streptavidin. Labels were visualised with diaminobenzidine (DAB) to produce a brown colour, and sections were counterstained with hematoxylin.

\section{Cell culture}

HK-2 cells (ATCC, American Type Culture Collection, Manassas, VA, USA) were cultured at $37^{\circ} \mathrm{C}$ in $95 \%$ air, 5\% $\mathrm{CO}_{2}$ atmosphere in DMEM plus DMEM-F12 medium (1:1) containing 10\% foetal bovine serum and $1 \%$ streptomycin-penicillin mixture. Depending on different experiments, HK-2 cells were pre-treated with serum-free medium for $24 \mathrm{~h}$, and then stimulated them with $5.6 \mathrm{mM}$ glucose plus $24.4 \mathrm{mM}$ mannitol (Control), HG (30 mM glucose) or HG plus SRT1720 $(2.5 \mu \mathrm{M})$ at indicated time points. Moreover, siRNAs were transfected into HK-2 cells. The siRNA targeting human HIF1A (5'-CGAGGAAGAACUAUGAACATT-3'), GLUT1 (5'-CCAAGAGUGUGCUAAAGAATT-3') or negative control (5'-UUCUCCGAACGUGUCACGUTT-3') were synthesised by Genepharma (Suzhou, China).

\section{Immunofluorescence assay}

Expressions of fibronectin, collagen IV and GLUT1 in renal tissues were detected using immunofluorescence assays. Frozen renal tissue sections were fixed with $4 \%$ paraformaldehyde at room temperature for $10 \mathrm{~min}$ and permeabilised in $0.2 \%$ Triton $\mathrm{X}-100$ for $10 \mathrm{~min}$. After 30 -min blocking with goat serum at $37^{\circ} \mathrm{C}$, renal tissues were incubated with primary antibodies in PBS overnight at $4^{\circ} \mathrm{C}$. After washing, renal tissues were incubated with TRITC/FITC-labelled secondary antibodies for $1 \mathrm{~h}$ at $37^{\circ} \mathrm{C}$. Images for fibronectin and GLUT1 were captured at 40x magnification using a fluorescence microscope (model No. BX63, Olympus). Images of collagen IV were obtained from a Leica DM2500 confocal microscope and quantitated using Image-Pro Plus 6.0 (Media Cybernetics).

Cells cultured in six-well chamber slides were fixed with $4 \%$ paraformaldehyde for $40 \mathrm{~min}$ at $4^{\circ} \mathrm{C}$ and permeabilised with $0.2 \%$ Triton $\mathrm{X}-100$ for $10 \mathrm{~min}$ at $37^{\circ} \mathrm{C}$. After washing, cells were incubated with antibodies against SIRT1, HIF1A, GLUT1, fibronectin, collagen IV, E-cadherin or $\alpha$-SMA overnight at $4^{\circ} \mathrm{C}$. Then, cells were incubated with the FITC-labelled secondary antibody (1:150) for $1 \mathrm{~h}$ at $37^{\circ} \mathrm{C}$. After washing with PBS, cell nuclei were stained with DAPI for $10 \mathrm{~min}$. Images were obtained using a Leica DM2500 confocal microscope.

\section{Western blot analyses}

Kidney tissues and cultured cells were homogenized in a lysis buffer (Millipore) according to the standard 
procedures. Nuclear proteins were extracted from mouse kidneys using a commercial nuclear extraction kit (Active Motif, Carlsbad, CA, USA). Protein concentrations were determined using the bicinchoninic acid protein assay kit (Solarbio, Beijing, China). For immunoblotting, same amounts of protein $(30-50 \mu \mathrm{g})$ were electrophoresed on SDS-PAGE and transferred onto PVDF membranes. Blots were incubated with primary antibodies (diluted to 1:1000 for SIRT1, HIF1A, GLUT1, SNAIL, fibronectin, collagen IV, E-cadherin, $\alpha$-SMA, TGFB1, CTGF, NOX4, NF-KBp65, $\beta$-actin and Histone $\mathrm{H} 3$ antibodies) overnight at $4^{\circ} \mathrm{C}$, and then with goat anti-rabbit or mouse IgG horseradish peroxidase conjugates, and finally scanned them using the GE-Amersham Imager 600 (General Electric Company, USA). Densitometry of the bands was performed using the NIH Image J 1.50 software.

\section{Immunocytochemistry}

HK-2 cells were fixed with $4 \%$ paraformaldehyde and permeabilised with $0.2 \%$ Triton-X 100 for $10 \mathrm{~min}$ at $37^{\circ} \mathrm{C}$. After rinsing with PBS, cells were incubated with antibody against SNAIL overnight at $4^{\circ} \mathrm{C}$. Then, cells were incubated with biotinylated secondary antibody and horseradish peroxidase-conjugated streptavidin. DAB was used to produce brown colour for visualisation.

\section{SIRT1 deacetylase activity assay}

SIRT1 activities in renal tissue and HK-2 cells were determined using a fluorometric SIRT1 assay kit (SigmaAldrich) (Li et al. 2017b). In brief, samples were incubated with $10 \mu \mathrm{L}$ SIRT1 substrate solution in the presence or absence of $\mathrm{NAD}^{+}$. Samples were incubated at $37^{\circ} \mathrm{C}$ for $1 \mathrm{~h}$. Next, $5 \mu \mathrm{L}$ of developing buffer was added to each well, samples were incubated at $37^{\circ} \mathrm{C}$ for $10 \mathrm{~min}$. The fluorescence intensities were measured using a microplate fluorometre (excitation wavelength $=360 \mathrm{~nm}$, emission wavelength $=450 \mathrm{~nm}$ ). Each experiment was performed in triplicates $(n=6)$.

\section{Reactive oxygen species (ROS) measurement}

Mitochondrial ROS were detected using the fluorescence MitoSOX red probe (Invitrogen). Cells were incubated in $5 \mu \mathrm{M}$ of MitoSOX Red reagent working solution at $37^{\circ} \mathrm{C}$ for $10 \mathrm{~min}$ and then washed three times with warm buffer. Fluorescence intensity was observed under a Leica DM2500 confocal microscope. Each experiment was performed in triplicate $(n=6)$.

\section{Statistical analysis}

Values are expressed as mean \pm standard error of means (s.E.M.). Statistical differences were assessed using one-way ANOVA for multiple groups and Bonferroni tests were carried out to determine the significant differences in multiple comparisons. All analyses were performed using the SPSS 21.0 statistical software package (SPSS). $P<0.05$ was considered significant.

\section{Results}

\section{Animal characteristics}

As shown in Table $1, \mathrm{db} / \mathrm{db}$ mice showed significant increase in blood glucose level and body weight compared with $\mathrm{db} / \mathrm{m}$ mice. SRT1720 treatment attenuated this increase in blood glucose level and body weight of $\mathrm{db} / \mathrm{db}$ mice. The 24-h urine albumin excretion, urine albumin/ creatinine ratio, serum creatinine and blood urea nitrogen values in $\mathrm{db} / \mathrm{db}$ mice were significantly higher than those in $\mathrm{db} / \mathrm{m}$ mice, which were alleviated by SRT1720 treatment.

\section{SRT1720 increased renal SIRT1 expression and activity in $\mathrm{db} / \mathrm{db}$ mice}

Immunohistochemistry staining showed that SIRT1 was mainly expressed in glomeruli and renal tubules and that renal SIRT1 expression was reduced in $\mathrm{db} / \mathrm{db}$ mice compared with that in $\mathrm{db} / \mathrm{m}$ mice. SRT1720 treatment significantly increased renal SIRT1 expression in $\mathrm{db} / \mathrm{db}$ mice (Fig. 1A). Western blot showed that diabetes was associated with decreased renal cortical SIRT1 expression and that this decrease was partially reversed by SRT1720 treatment (Fig. 1B). Similarly, SRT1720 treatment markedly increased renal SIRT1 activity in $\mathrm{db} / \mathrm{db}$ mice (Fig. 1C). These results confirmed that SRT1720 regulates renal SIRT1 expression and activity in $\mathrm{db} / \mathrm{db}$ mice.

\section{SRT1720 prevented renal extracellular matrix (ECM) accumulation and fibrosis in $\mathrm{db} / \mathrm{db}$ mice}

The mesangial area in $\mathrm{db} / \mathrm{db}$ mice kidneys was larger than that in $\mathrm{db} / \mathrm{m}$ mice, and SRT1720 treatment significantly reduced this area (Fig. 2A and B). As depicted in the Masson Trichrome staining, increased interstitial fibrosis in the kidneys of $\mathrm{db} / \mathrm{db}$ mice was observed compared with that in kidneys of $\mathrm{db} / \mathrm{m}$ mice, and this increase 
Table 1 Physical and metabolic parameters after completion of the study. Data are presented as the mean \pm S.E.M. ( $n=6$ ).

\begin{tabular}{|c|c|c|c|c|c|c|c|}
\hline Group & BG $(\mathrm{mmol} / \mathrm{L})$ & BW (g) & $\mathbf{K W}$ (mg) & BUN (mmol/L) & $\mathbf{S c r}(\mu \mathrm{mol} / \mathrm{L})$ & UAE ( $\mu \mathrm{g} / 24 \mathrm{~h})$ & UACR $(\mu \mathrm{g} / \mathrm{mg})$ \\
\hline $\mathrm{db} / \mathrm{m}$ & $13.98 \pm 0.89$ & $25.74 \pm 0.84$ & $194.42 \pm 18.57$ & $7.67 \pm 1.21$ & $23.95 \pm 3.45$ & $5.71 \pm 2.76$ & $14.62 \pm 2.41$ \\
\hline $\mathrm{db} / \mathrm{db}$ & $35.85 \pm 6.51$ * & $60.35 \pm 3.38 *$ & $217.97 \pm 27.31$ & $14.63 \pm 3.27 *$ & $54.41 \pm 9.07 *$ & $308.57 \pm 17.14^{*}$ & $118.24 \pm 13.52 *$ \\
\hline$d b / d b+S R T$ & $31.48 \pm 7.64^{\#}$ & $51.28 \pm 3.58^{\#}$ & $220.83 \pm 22.33$ & $7.99 \pm 1.47 \#$ & $34.66 \pm 1.54^{\#}$ & $226.67 \pm 54.01 \#$ & $65.78 \pm 9.76^{\#}$ \\
\hline
\end{tabular}

was reversed by SRT1720 treatment (Fig. 2A and C). Moreover, SRT1720 affected the expressions of renal fibrosis markers, collagen IV and fibronectin (Fig. 2A). As indicated by immunofluorescence, $\mathrm{db} / \mathrm{db}$ mice exhibited increased collagen IV expression compared with $\mathrm{db} / \mathrm{m}$ mice. However, this increased collagen IV expression was reduced by SRT1720 treatment (Fig. 2A and D). Moreover, SRT1720 showed inhibitory effect on increased fibronectin expression in the kidneys of $\mathrm{db} / \mathrm{db}$ mice compared with that in untreated mice (Fig. 2A and E). These results demonstrated that SRT1720 can diminish ECM accumulation and fibrosis in the kidneys of $\mathrm{db} / \mathrm{db}$ mice.

\section{Effect of SRT1720 on renal expression of E-cadherin, $\alpha$-SMA, HIF1A, GLUT1 and SNAIL in $\mathrm{db} / \mathrm{db}$ mice}

Epithelial marker E-cadherin and mesenchymal marker $\alpha$-SMA were examined to determine effects of SRT1720 on renal EMT. As shown in immunohistochemistry, E-cadherin expression was lower but $\alpha$-SMA expression was higher in the renal tubules of $\mathrm{db} / \mathrm{db}$ mice than in those of $\mathrm{db} / \mathrm{m}$ mice, and the trends were reversed by SRT1720 treatment (Fig. 3A). Western blotting corroborated these results (Fig. 3B).

To investigate mechanisms underlying the fibrosis inhibitory effects of SRT1720, expressions of HIF1A, GLUT1 and SNAIL were detected. As shown in Fig. 3C, HIF1A was expressed in the renal tubules and glomeruli.
Renal HIF1A expression was significantly higher in $\mathrm{db} / \mathrm{db}$ mice than in $\mathrm{db} / \mathrm{m}$ mice. Importantly, HIF1A expression in diabetic kidneys was inhibited by SRT1720 treatment. Similar results were observed in terms of GLUT1 and SNAIL expressions, which were mainly expressed in the renal tubules as shown in immunofluorescence and immunohistochemistry images (Fig. 3C). Western blot revealed that renal HIF1A, GLUT1 and SNAIL expressions were significantly higher in $\mathrm{db} / \mathrm{db}$ mice than in $\mathrm{db} / \mathrm{m}$ mice, but they were decreased after SRT1720 treatment (Fig. 3D). Together, these results demonstrated that SRT1720 conferred regulatory effect on EMT of tubular cells and expressions of HIF1A, GLUT1 and SNAIL in $\mathrm{db} / \mathrm{db}$ mice.

\section{SRT1720 inhibited renal TGFB1, CTGF and NF-KB expressions and reduced oxidative stress in $\mathrm{db} / \mathrm{db}$ mice}

TGFB1, the most potent inducer of renal fibrosis in diabetes, modulates ECM protein expression either alone or together with CTGF (Okada et al. 2005). Renal TGFB1 and CTGF expressions were significantly increased in $\mathrm{db} / \mathrm{db}$ mice compared with those in $\mathrm{db} / \mathrm{m}$ mice, and SRT1720 treatment suppressed this effect (Fig. 4A and B). A previous study has shown that NF-KB activation is associated with inflammation and fibrosis in DN (Sun et al. 2016). NF-KB was activated in diabetic kidney,

A

$\mathrm{db} / \mathrm{m}$

$\mathrm{db} / \mathrm{db}$

$\mathrm{db} / \mathrm{db}+\mathrm{SRT}$

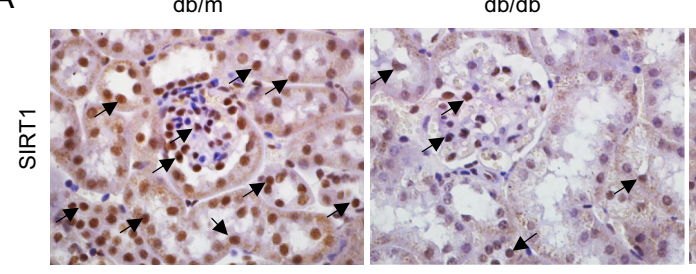

B
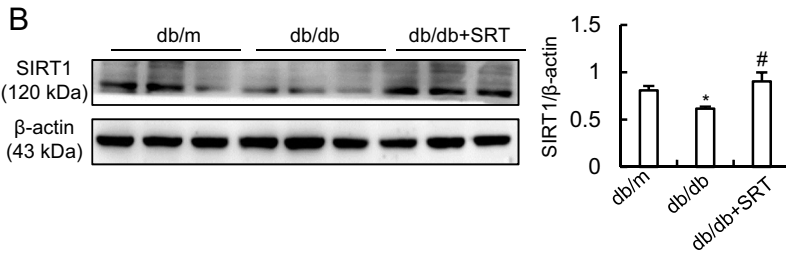

C

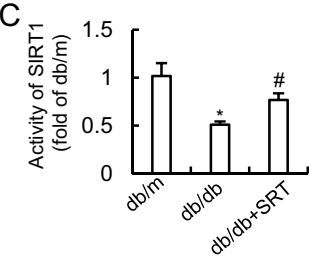

Figure 1

Effect of SRT1720 on SIRT1 expression and activity in $\mathrm{db} / \mathrm{db}$ mice. (A) Immunohistochemical staining images of SIRT1 in kidney sections (scale bar, $20 \mu \mathrm{m}$ ). Arrows indicate positive SIRT1staining. (B) SIRT1 expression was assessed by Western blot in renal cortical homogenates. (C) SIRT1activity. Data are expressed as mean \pm S.E.M. $(n=6)$. ${ }^{\star} P<0.05$ vs $\mathrm{db} / \mathrm{m} ; \# P<0.05 \mathrm{vs} \mathrm{db/db}$. https://joe.bioscientifica.com https://doi.org/10.1530/JOE-18-0536 (c) 2019 Society for Endocrinology Published by Bioscientifica Ltd.
Printed in Great Britain 
A
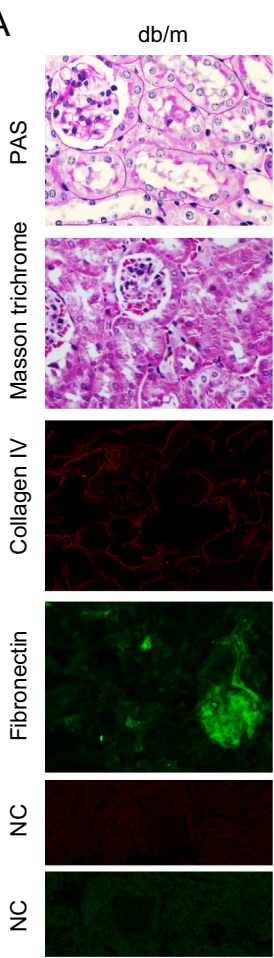

E
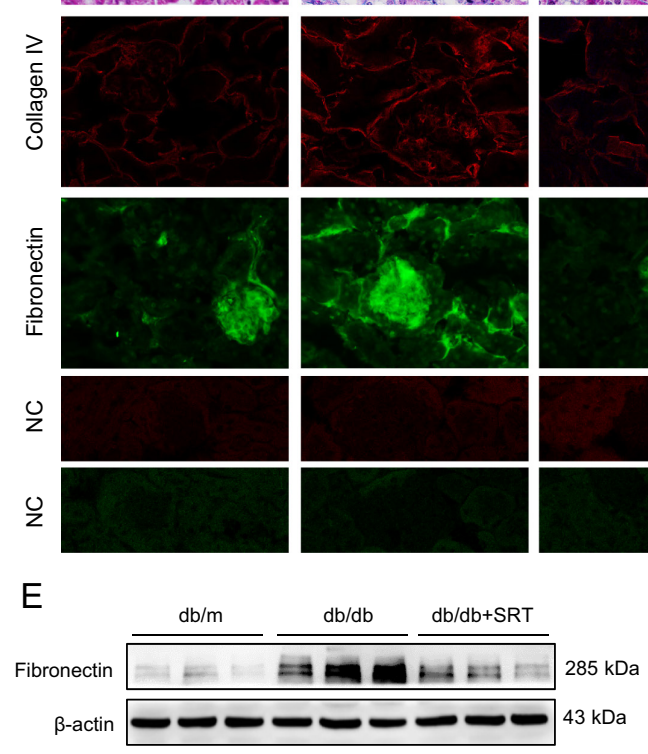

$\mathrm{db} / \mathrm{db}+\mathrm{SRT}$
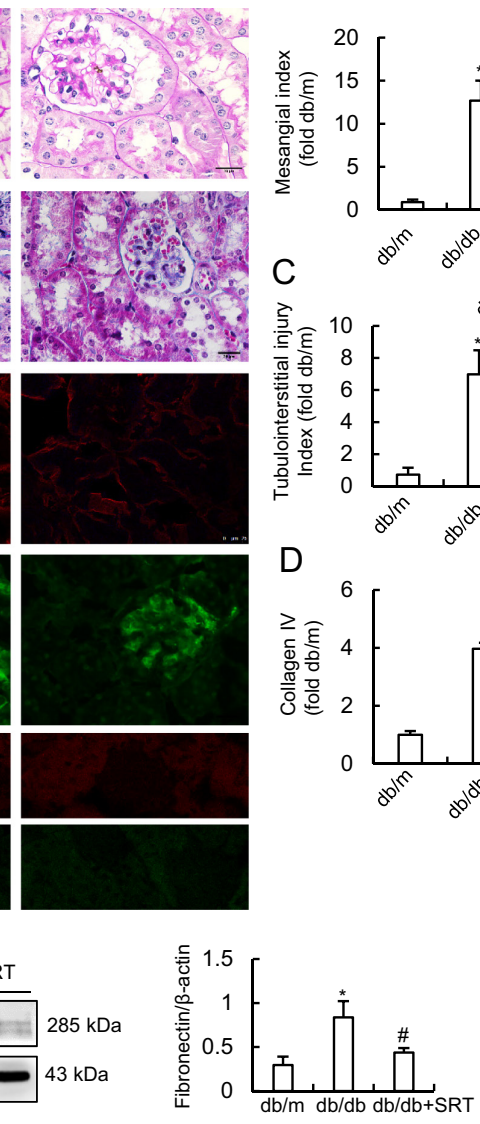

B
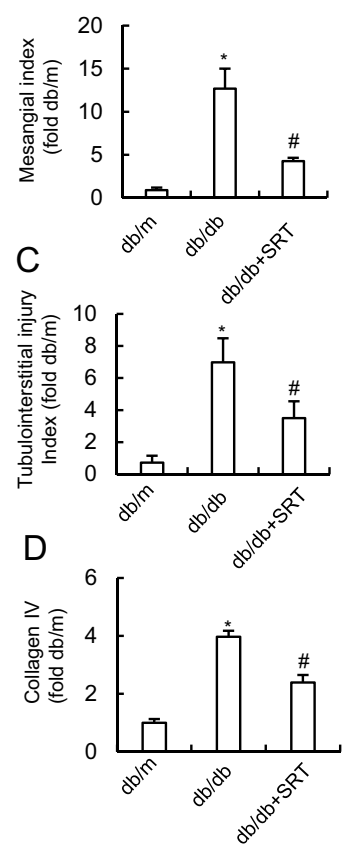

Figure 2

Effect of SRT1720 on renal histopathology. (A) Staining of kidney with periodic acid Schiff (PAS) and Masson Trichrome, and immunofluorescence staining for fibronectin and collagen IV (scale bar, $20 \mu \mathrm{m})$. NC, immunofluorescence images obtained from three groups without primary antibody as a negative control. Mesangial index (B), tubulointerstitial injury index (C) and semi-quantitative analyses of collagen IV (D) were measured. (E) Fibronectin expression was detected using Western blot. Data are expressed as mean \pm S.E.M. $(n=6) .{ }^{*} P<0.05$ vs $\mathrm{db} / \mathrm{m} ;{ }^{*} P<0.05$ vs $\mathrm{db} / \mathrm{db}$. and SRT1720 treatment significantly reduced the NF-KB transfer from the cytoplasm to nucleus in $\mathrm{db} / \mathrm{db}$ mice compared with that in untreated mice (Fig. 4A and C). Furthermore, NOX4 expression in diabetic kidneys was evaluated. Increased NOX4 expression in diabetic kidneys was significantly attenuated by SRT1720 treatment (Fig. 4A and D). Moreover, levels of 8-OHdG, a marker of oxidative stress, were measured in renal tissues and urine. SRT1720 treatment lowered 8-OHdG levels in renal tissues and urine of $\mathrm{db} / \mathrm{db}$ mice compared with those in renal tissues and urine of untreated mice (Fig. 4A and E).

\section{SRT1720 blocked HG-induced EMT and ECM proteins expression in HK-2 cells}

SIRT1 expression and activity were decreased in HG-treated HK-2 cells compared with those in control group. SRT1720 treatment stimulated SIRT1 expression and activity in HG-treated HK-2 cells (Fig. 5A, B and C). Effects of SRT1720 on $\mathrm{HG}$-induced EMT and ECM protein expression in
HK-2 cells were investigated. Immunofluorescent staining and Western blot revealed that HG-induced HK-2 cells exhibited E-cadherin downregulation and $\alpha$-SMA upregulation. However, SRT1720 treatment attenuated this HG-induced decrease in E-cadherin expression and increase in $\alpha$-SMA expression (Fig. 5A and B). In control group, HK-2 cells exhibited a typical epithelial cuboidal shape, but HG treatment produced spindle-like shape. However, this HG-induced morphological change was reversed by SRT1720 treatment (Fig. 5D). In addition, fibronectin and collagen IV expressions dramatically increased in HG-treated HK-2 cells compared with those in control group. Exposure to SRT1720 significantly reduced HG-induced fibronectin and collagen IV expressions in HK-2 cells (Fig. 5E and F). Next, effects of SRT1720 on HG-induced mitochondrial ROS generation were evaluated in HK-2 cells. As shown in Fig. 5G, ROS generation was inhibited by SRT1720 treatment in HK-2 cells under HG conditions. These results indicated that SRT1720 exerts inhibitory effects on HG-induced EMT and ECM protein expression in HK-2 cells. https://joe.bioscientifica.com https://doi.org/10.1530/JOE-18-0536
(C) 2019 Society for Endocrinology Published by Bioscientifica Ltd.
Printed in Great Britain 


\begin{tabular}{l|l|l}
$\begin{array}{l}\text { Journal of } \\
\text { Endocrinology }\end{array}$ & $\begin{array}{l}\text { W Han, C Wang, Z Yang } \\
\text { et al. }\end{array}$ & $\begin{array}{l}\text { SRT1720 inhibits renal fibrosis } \\
\text { in diabetes }\end{array}$
\end{tabular}

A $\quad \mathrm{db} / \mathrm{m}$

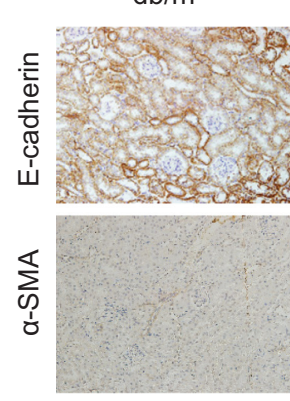

$\mathrm{db} / \mathrm{db}$

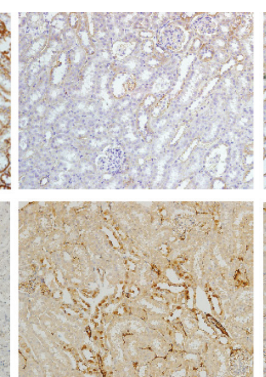

C

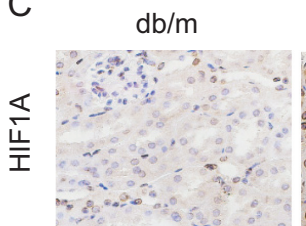

$\mathrm{db} / \mathrm{db}$
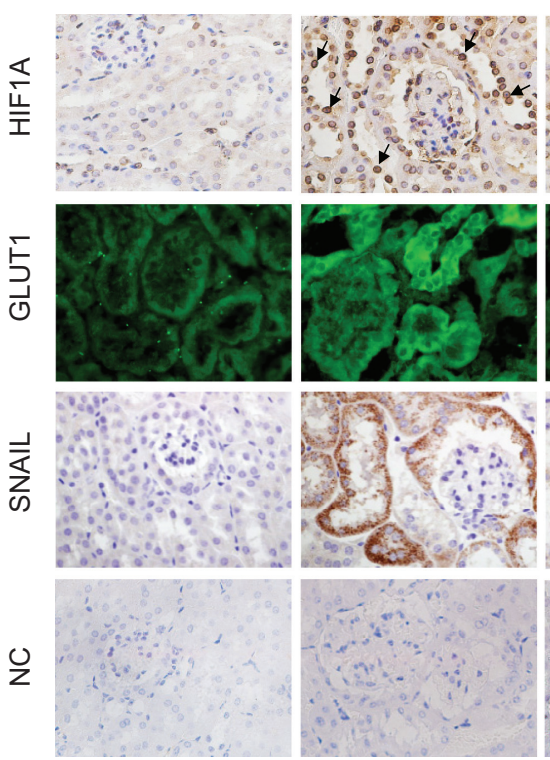

$\mathrm{db} / \mathrm{db}+\mathrm{SRT}$

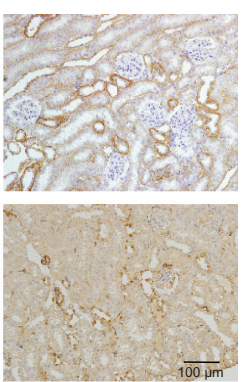

$\mathrm{db} / \mathrm{db}+\mathrm{SRT}$
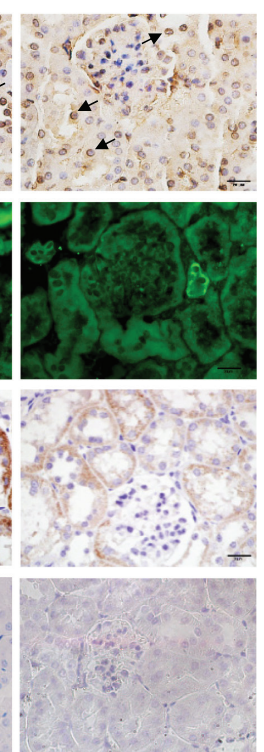

B

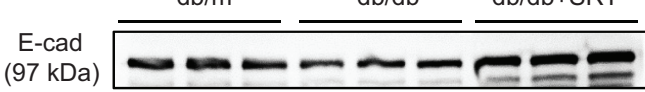
a-SMA (42 kDa) $\beta$-actin (43 kDa)
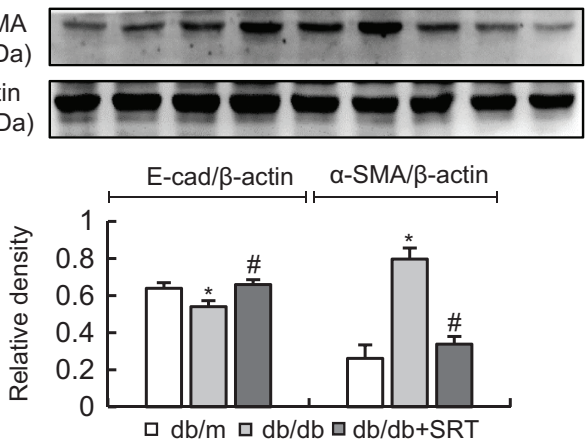

D
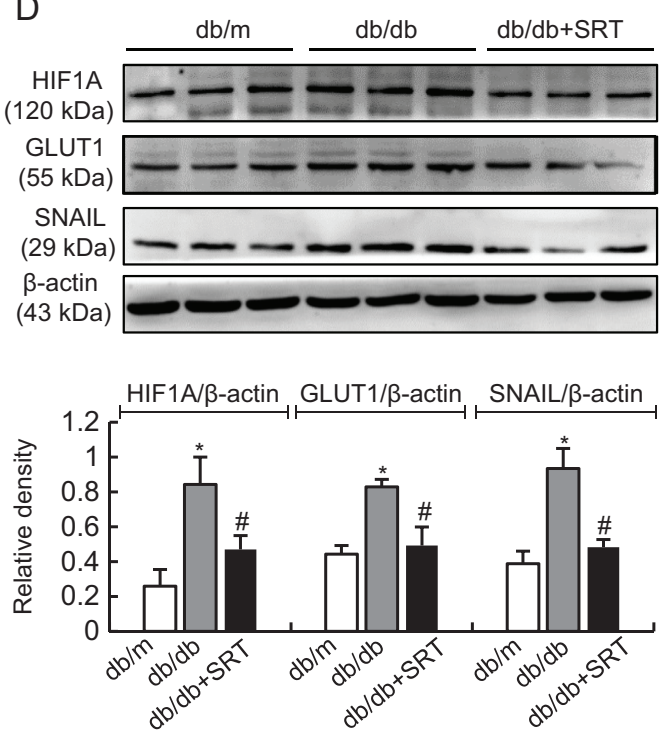

\section{Figure 3}

Effect of SRT1720 on renal expression of E-cadherin, $\alpha$-SMA, HIF1A, GLUT1 and SNAIL in db/db mice. (A) Immunohistochemical staining of E-cadherin and $\alpha$-SMA in kidney sections (scale bar, $100 \mu \mathrm{m}$ ). (B) Expressions of E-cadherin and $\alpha$-SMA were assessed using Western blot. (C) Representative kidney sections of HIF1A and SNAIL expression detected by immunohistochemistry staining and GLUT1 expression detected by immunofluorescence staining (scale bar, $20 \mu \mathrm{m}$ ). Arrows indicate positive HIF1A staining. NC, immunohistochemistry images obtained from three group without primary antibody as a negative control. (D) Expressions of HIF1A, GLUT1 and SNAIL in renal cortex was detected using Western blot. Data are expressed as mean \pm S.E.M. $(n=6)$ $\star P<0.05$ vs $\mathrm{db} / \mathrm{m} ; \# P<0.05$ vs $\mathrm{db} / \mathrm{db}$.

\section{SRT1720 inhibited HG-induced HIF1A, GLUT1 and SNAIL expressions in HK-2 cells}

HIF1A expression was increased in HG-treated HK-2 cells, but this effect was reversed by SRT1720 treatment (Fig. 6A and C), suggesting that SIRT1 inhibited HIF1A expression in HG-treated HK-2 cells under normoxic conditions. Next, effects of SRT1720 on GLUT1 and SNAIL expressions were evaluated in HK-2 cells. Compared with GLUT1 and SNAIL expressions in the control group, expressions in HG group significantly increased, but SRT1720 treatment suppressed HG-induced increase in GLUT1 and SNAIL expressions in HK-2 cells (Fig. 6). These data demonstrated that SRT1720 can suppress HIF1A, GLUT1 and SNAIL expressions in HG-induced HK-2 cells.

\section{Knockdown of HIF1A or GLUT1 inhibited HG-induced EMT and ECM protein expression in HK-2 cells}

To explore effects of HIF1A and GLUT1 on HG-induced EMT and ECM protein expression, HK-2 cells were transfected with siRNA against either HIF1A or Glut1. As shown in Fig. 7A, HIF1A knockdown efficiently reduced GLUT1 protein level in HG-induced HK-2 cells, but GLUT1 siRNA 


\begin{tabular}{l|l|l|r|r|}
$\begin{array}{l}\text { Journal of } \\
\text { Endocrinology }\end{array}$ & $\begin{array}{l}\text { W Han, C Wang, Z Yang } \\
\text { et al. }\end{array}$ & $\begin{array}{l}\text { SRT1720 inhibits renal fibrosis } \\
\text { in diabetes }\end{array}$ & $\mathbf{2 4 1 : 1}$ & $\mathbf{9 2}$ \\
\hline
\end{tabular}
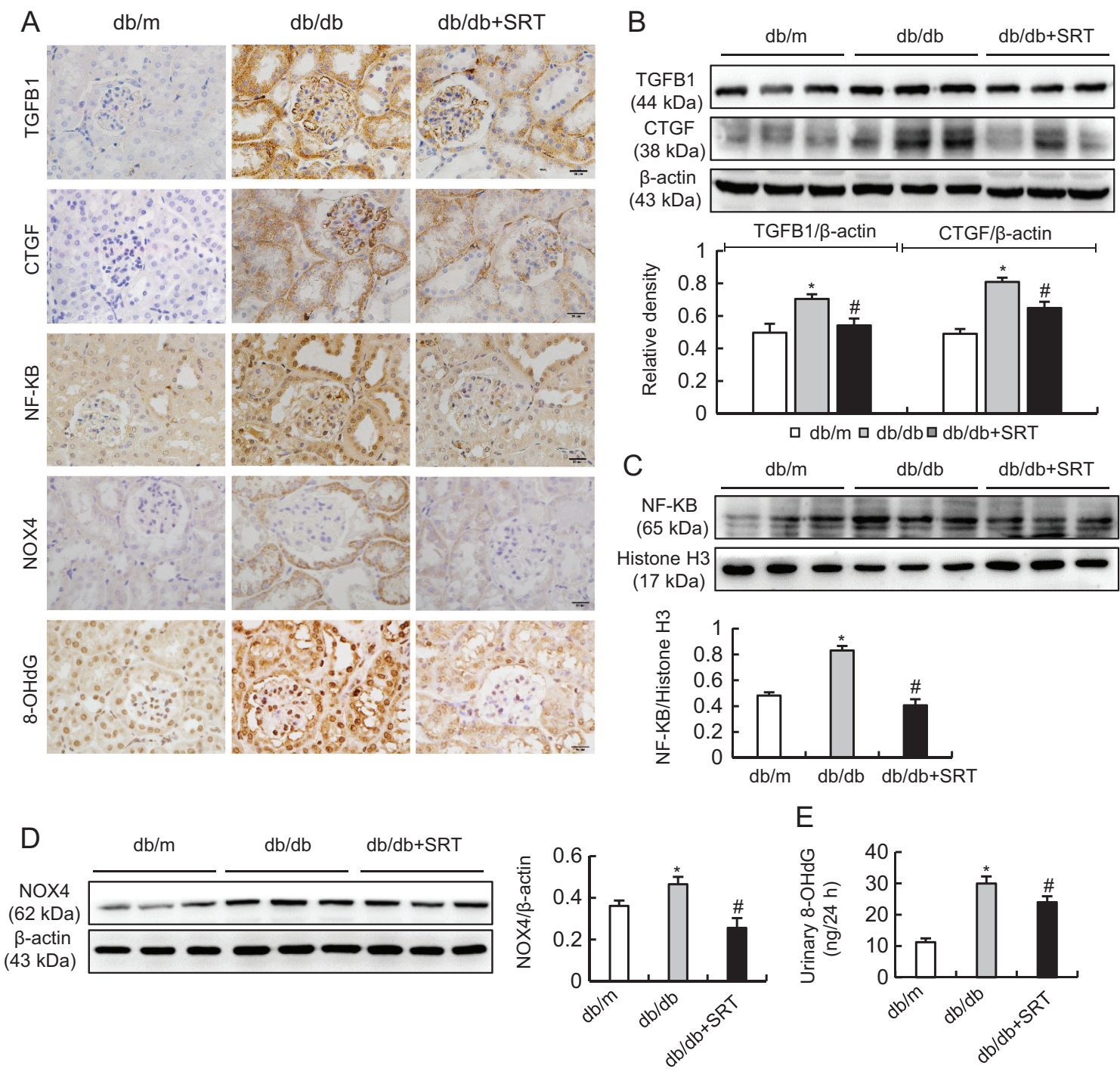

\section{Figure 4}

Effect of SRT1720 on expression of TGFB1, CTGF, NF-KB p65, NOX4 and 8-OHdG in diabetic kidneys. (A) Immunohistochemical staining of TGFB1, CTGF, NF-KB p65, NOX4 and 8-OHdG in kidney sections (Scale bar, $20 \mu \mathrm{m}$ ). (B) Protein levels of TGFB1 and CTGF were assessed using Western blot. (C) NF-KB p65 expression in nuclear extracts was assessed using Western blot, and the relative intensity of nuclear NF-KB p65 was normalized against that of Histone H3. (D) NOX4 expression was detected using Western blot. (E) Twenty-four-hour urinary 8-OHdG excretion was measured using ELISA. Data are expressed as mean \pm s.E.M. $(n=6)$. * $P<0.05 \mathrm{vs} \mathrm{db/m;} \# P<0.05 \mathrm{vs} \mathrm{db/db}$.

did not affect HG-induced HIF1A expression. However, HG-induced upregulation of SNAIL was significantly declined in HK-2 cells transfected with HIF1A or GLUT1 siRNA. Silencing HIF1A or GLUT1 reversed effects of HG on E-cadherin and $\alpha$-SMA expressions in HK-2 cells (Fig. 7B). Moreover, HG-induced fibronectin and collagen IV expressions were abolished by HIF1A or GLUT1 siRNA in HK-2 cells (Fig. 7C). Overall, these results indicated that HIF1A and its target factors mediate HG-induced EMT and ECM protein expression in HK-2 cells.

\section{Expressions of SIRT1 and HIF1A in renal tissue samples from patients with DN}

SIRT1 and HIF1A expressions were assessed in renal tissue samples of patients with DN. Immunohistochemical staining showed that SIRT1 expression was markedly reduced in diabetic kidneys compared with that in normal kidneys (Fig. 8). Moreover, faint HIF1A staining was observed in normal kidneys, whereas prominent HIF1A staining was observed in diabetic kidneys (Fig. 8). 
A
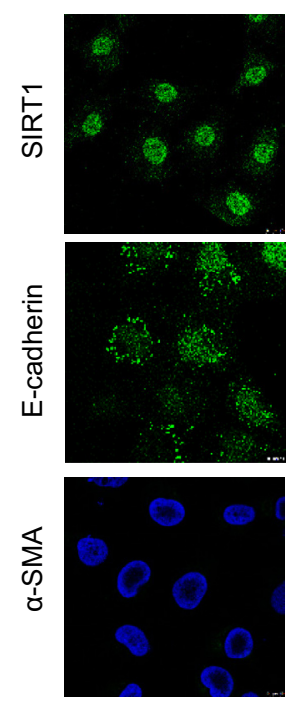

C

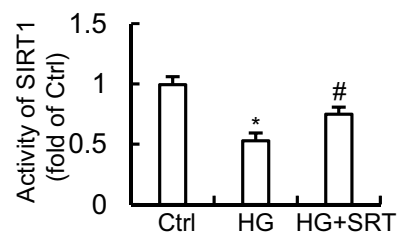

E
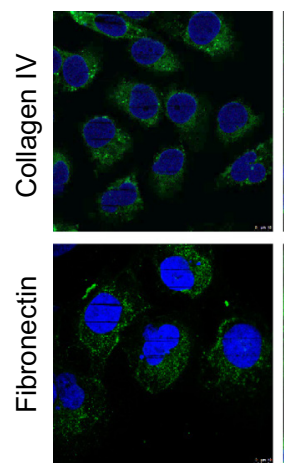

G

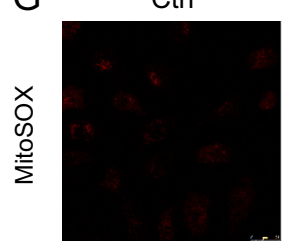

HG

HG
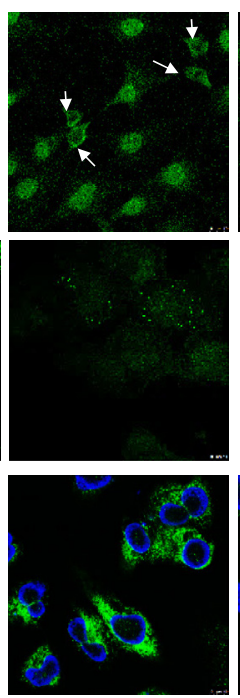

D
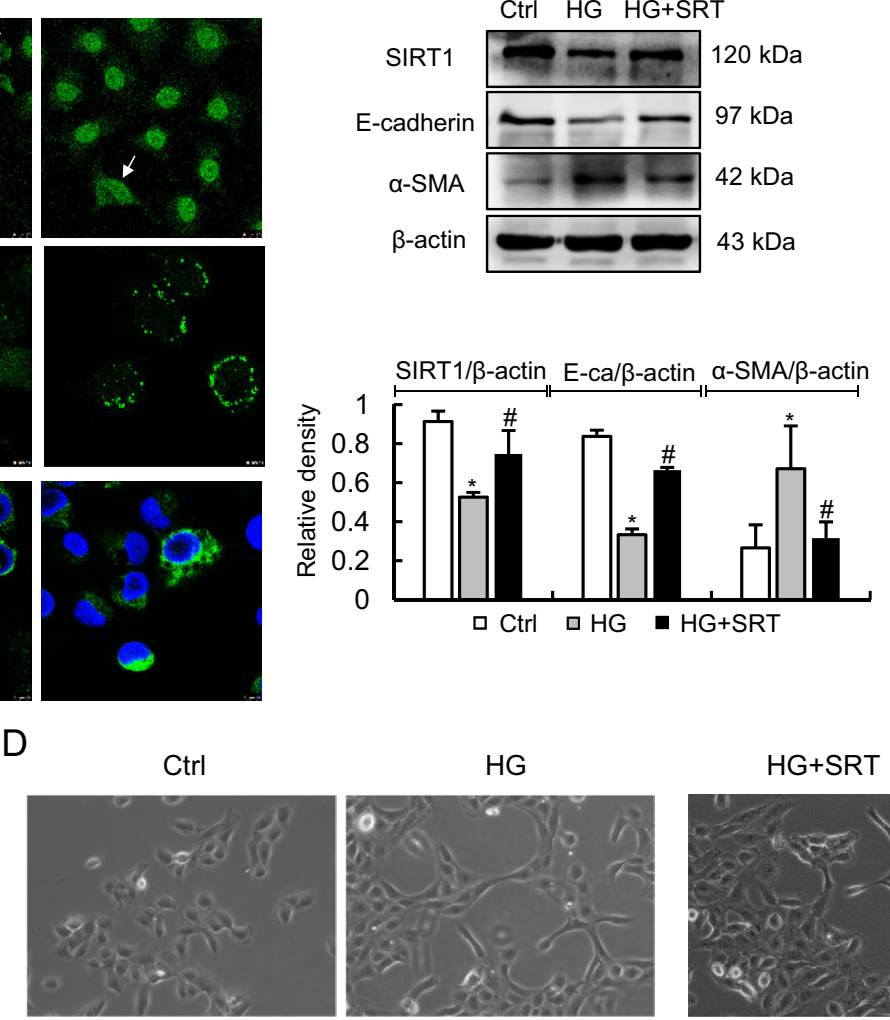

F
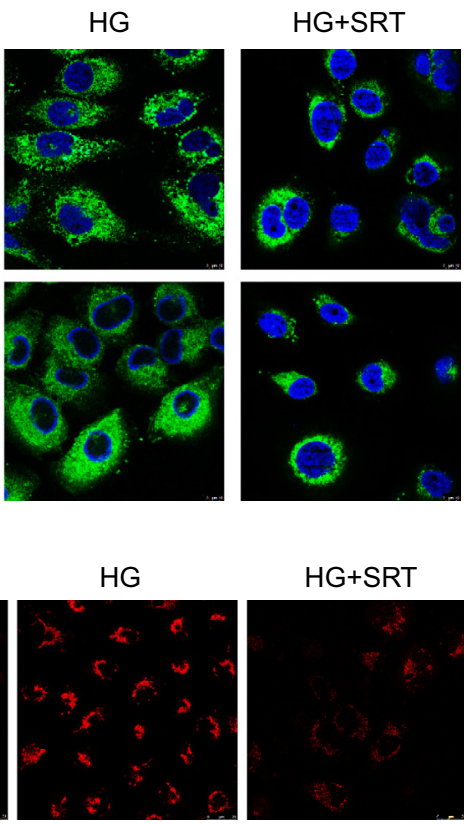

B

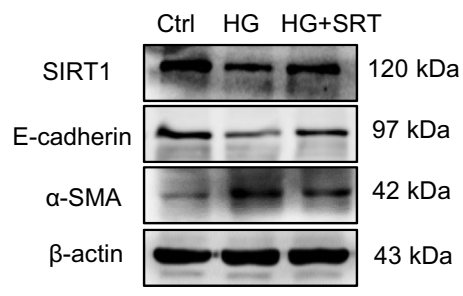

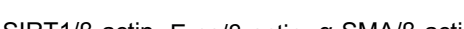

a Ctrl $\quad$ a $H G \backsim H G+S R T$
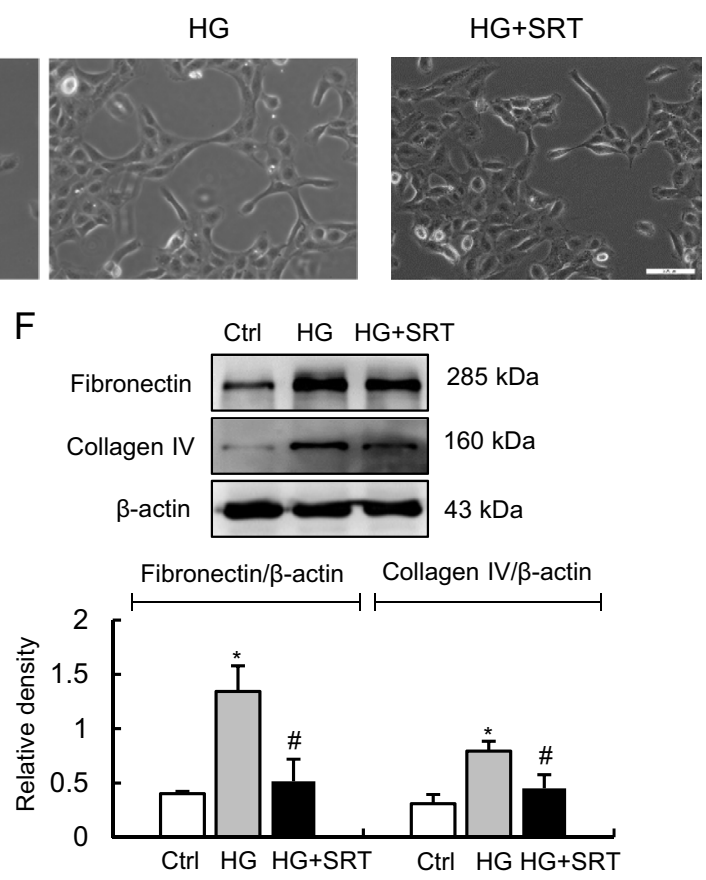

$H G+S R T$
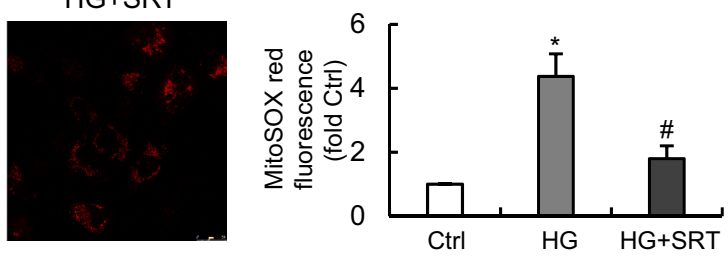

\section{Figure 5}

Effects of SRT1720 on HG-induced EMT, fibronectin and collagen IV expressions, and ROS generation in HK-2 cells. (A) Representative images of immunofluorescence staining for SIRT1, E-cadherin and $\alpha$-SMA in HK-2 cells. (B) Expressions of SIRT1, E-cadherin and $\alpha$-SMA were detected using Western blot. (C) SIRT1 activity in HK-2 cells. (D) Morphological changes of HK-2 cells were analysed under an inverted microscope. (E) Representative images of immunofluorescence for fibronectin and collagen IV in HK-2 cells. (F) Fibronectin and collagen IV expressions were detected using Western blot. (G) Mitochondrial ROS generation was assessed using the fluorescence probe MitoSOX Red. Note: Ctrl, $5.6 \mathrm{mM}$ glucose plus $24.4 \mathrm{mM}$ mannitol; HG, high glucose $(30 \mathrm{mM}) ; \mathrm{HG}+\mathrm{SRT}$, HG + SRT1720 (2.5 $\mu \mathrm{M})$. Data are expressed as mean \pm S.E.M. $(n=6)$. * $P<0.05$ vs Ctrl; \# $P<0.05$ vs HG. 
A Ctrl
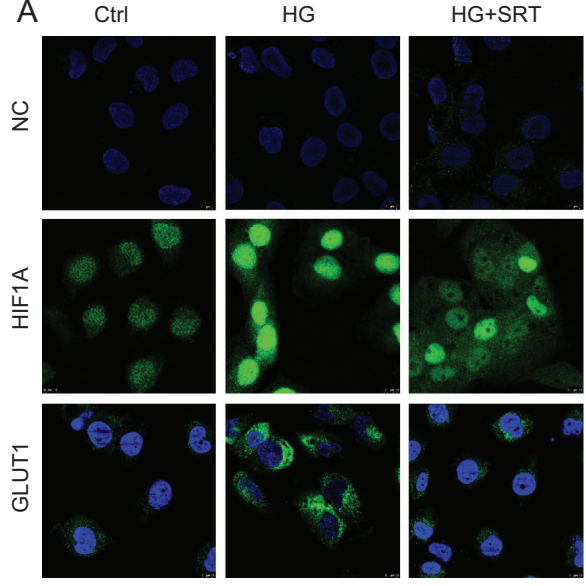

B Ctrl

HG

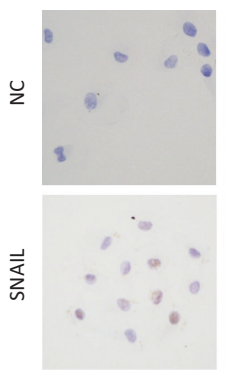

$H G+S R T$

A

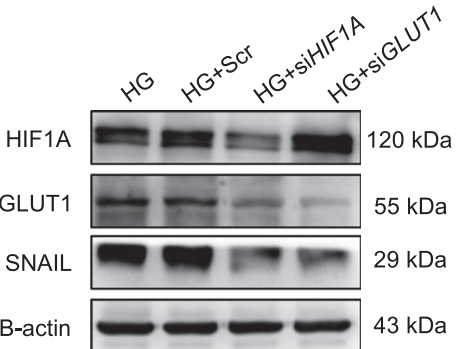

B

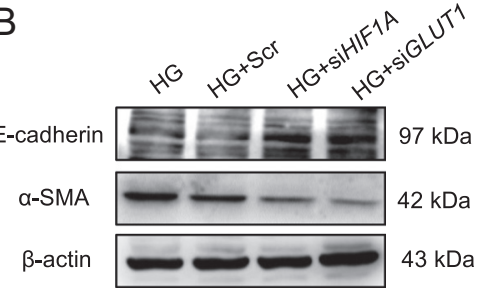

C
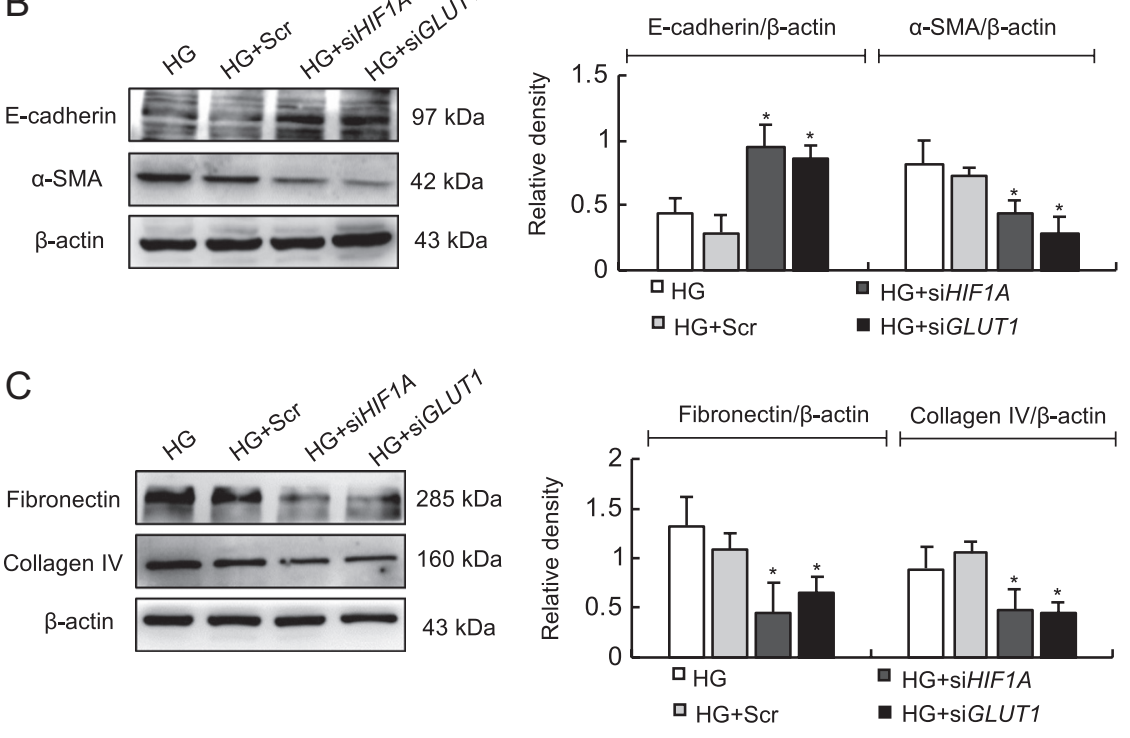

\section{Figure 6}

Effect of SRT1720 on expression of HIF1A, GLUT1 and SNAIL in HK-2 cells. (A) Representative images of immunofluorescence staining for HIF1A and GLUT1. NC, immunofluorescence images obtained from three group without primary antibody as a negative control. (B) Representative images of immunochemistry for SNAIL. NC, immunochemistry images obtained from three group without primary antibody as a negative control. (C) Expressions of HIF1A, GLUT1 and SNAIL were assessed by Western blot. Note: Ctrl, $5.6 \mathrm{mM}$ glucose plus $24.4 \mathrm{mM}$ mannitol; $\mathrm{HG}$, high glucose $(30 \mathrm{mM}) ; \mathrm{HG}+\mathrm{SRT}, \mathrm{HG}+\mathrm{SRT} 1720(2.5 \mu \mathrm{M})$. Data are presented as mean \pm S.E.M. $(n=6)$. $\star P<0.05$ vs $\mathrm{Ctrl} ; \# P<0.05$ vs HG.

\section{Figure 7}

Effects of HIF1A or GLUT1 knockdown on expression of SNAIL, E-cadherin, $\alpha$-SMA, fibronectin and collagen IV in HG-treated HK-2 cells. HK-2 cells were transfected with HIF1A siRNA or GLUT1 siRNA and treated with HG for $48 \mathrm{~h}$. (A) Protein levels of HIF1A, GLUT1 and SNAIL were detected using Western blot. (B) Protein levels of E-cadherin and $\alpha$-SMA were detected using Western blot. (C) Protein levels of fibronectin and collagen IV were detected using Western blot. Note: $\mathrm{HG}$, high glucose $(30 \mathrm{mM}) ; \mathrm{HG}+\mathrm{Scr}$, $\mathrm{HG}+$ scramble; $\mathrm{HG}+$ siHIF1A, HG + HIF1A siRNA: HG + siGLUT1, HG + GLUT1 siRNA. Data are expressed as mean \pm S.E.M. $(n=6)$. * $P<0.05$ vs HG. 

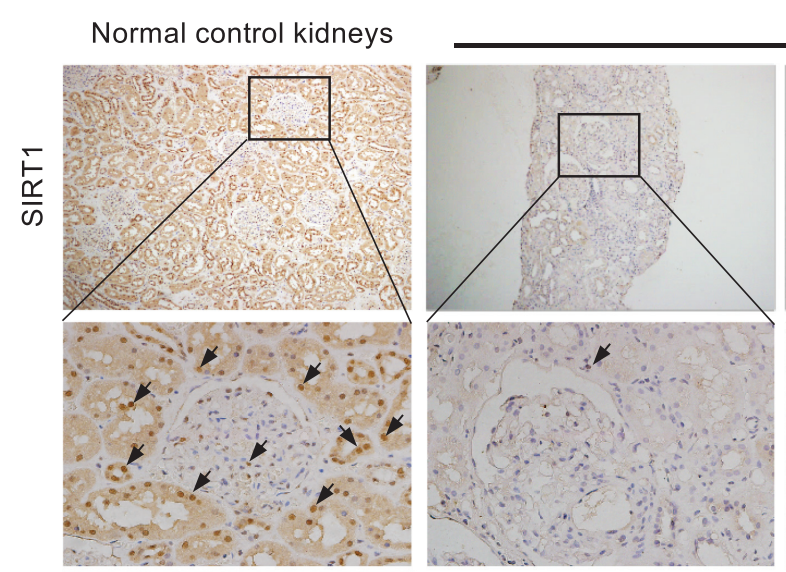

Diabetic kidneys
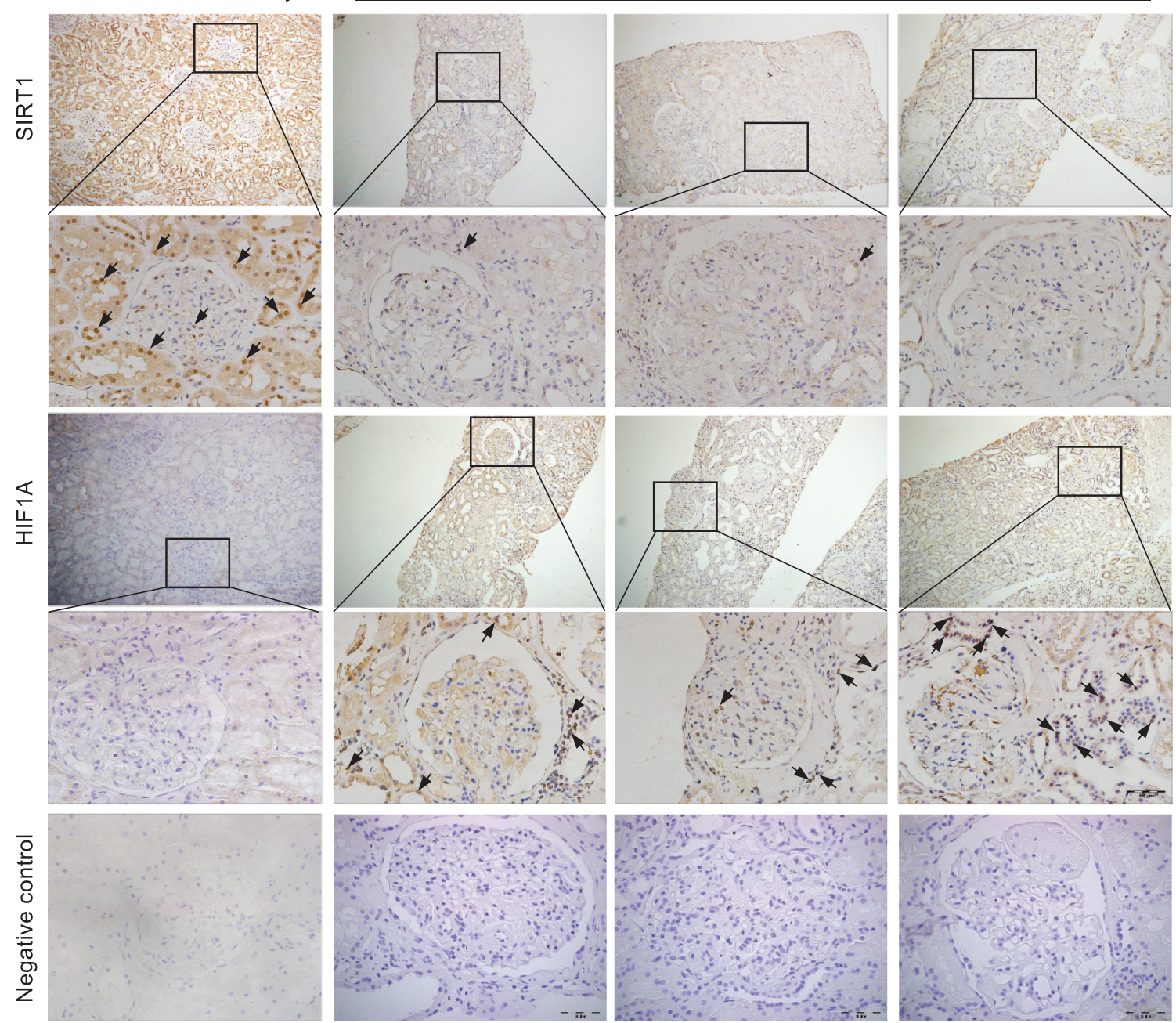

\section{Figure 8}

Expressions of SIRT1 and HIF1A in kidneys of patients with DN or normal control kidneys were detected using immunohistochemistry staining. Arrows indicate the positive SIRT1 or HIF1A staining. Scale bar, $50 \mu \mathrm{m}$. Negative control, immunohistochemistry images obtained from four groups without primary antibody as a negative control.

These observations were consistent with those in animal models, further supporting the notion that abnormal SIRT1 and HIF1A expression were associated with DN development.

\section{Discussion}

This study was undertaken to assess whether SRT1720, an SIRT1 activator, can ameliorate renal dysfunction and attenuate renal fibrosis in DN and to elucidate the possible underlying mechanisms. Our results show that SIRT1 expression and activity were decreased in kidneys of $\mathrm{db} / \mathrm{db}$ mice and administration of SRT1720 reversed these changes. SRT1720 significantly attenuated glomerular hypertrophy, mesangial expansion, glomerulosclerosis and interstitial fibrosis in $\mathrm{db} / \mathrm{db}$ mice. In addition, in vitro results demonstrated that SRT1720 inhibits HG-induced fibrotic responses through SIRT1/HIF1A/GLUT1/SNAIL pathway.

Numerous studies have shown that SIRT1 exerts protective effects against $\mathrm{DN}$ by reducing oxidative stress, apoptosis, inflammation and lipotoxicity (Kitada et al. 2011, Kim et al. 2013). In this study, decreased SIRT1 expression was detected in kidneys of $\mathrm{db} / \mathrm{db}$ mice, as well as in samples of patients with DN. This result is consistent with previous reports (Kim et al. 2013, Lo et al. 2017). Several studies identify NOX4 as a key source of ROS responsible for kidney injury in diabetes (Gorin et al. 2005, Jha et al. 2014). Inhibition of NOX4 alleviated 
oxidative stress and renal injury in diabetic nephropathy (Jha et al. 2014). Previous studies have shown that NF-KB activation has a role in renal inflammation and fibrosis of the progression of DN (Schmid et al. 2006, NavarroGonzalez et al. 2011). Reportedly, SIRT1 mediated antiinflammatory and anti-oxidative effects by inhibiting NF-KB activation and NOX4 expression, thereby protecting against kidney injury under diabetic conditions (Liu et al. 2014, Li et al. 2017a). Our findings demonstrated that SRT1720 administration inhibited NF-KB activation, NOX4 expression and oxidative stress via SIRT1 induction in diabetic nephropathy.

Tubulointerstitial fibrosis is important for the prognosis of DN (Gilbert \& Cooper 1999). Previous studies have confirmed that TGFB1 play a central role in various fibrogenic processes, including ECM accumulation, and glomerular and tubulointerstitial fibrosis (Lan 2011). CTGF acts downstream of TGFB1 to promote chronic tubulointerstitial fibrosis in DN (Wang et al. 2001). In our study, SRT1720 ameliorated ECM accumulation, renal fibrosis and TGFB1 and CTGF expressions in the kidneys of $\mathrm{db} / \mathrm{db}$ mice. These results suggest that SRT1720 inhibits renal fibrosis through inhibition of TGFB1 and CTGF expression in diabetic mice.

HIF1A is highly expressed in glomerular and tubulointerstitial lesions of diabetic animal models and patients with DN (Higgins et al. 2007, Rosenberger et al. 2008, Isoe et al. 2010, Takiyama et al. 2011). YC-1, an HIF-1 inhibitor, reduced renal HIF1A expression and exerted promising renal protective effect in type 1 diabetic mice (Nayak et al. 2016). GLUT1 is constitutively expressed in diabetic kidney and promotes hyperglycemia-induced renal injury (Mogyorósi \& Ziyadeh 1999, Ricci et al. 2006). Renal GLUT1 expression was significantly inhibited by YC-1 treatment in diabetic OVE26 mice (Nayak et al. 2016). Besides, GLUT1 was defined as a critical downstream target of HIF- $1 \alpha$ mediating high glucose-induced matrix expression through the NOX4 in glomerular mesangial cells (Nayak et al. 2016). SIRT1 has been reported to modulate HIF1A expression under hypoxic stress (Lim et al. 2010, Bae et al. 2013). In the present study, we observed SIRT1 activator SRT1720 inhibited HIF1A and GLUT1 expression in the kidney of $\mathrm{db} / \mathrm{db}$ mice and HK-2 cells treated with high glucose. In addition, high glucoseinduced GLUT1 expression was prevented by transfection of HIF1A siRNA in HK-2 cells. EMT is considered essential for the development of renal fibrosis in DN (Liu 2004). Snail1 knockdown could reverse the fibrosis via inhibition of EMT in a fibrotic mouse model (Grande et al. 2015).
Moreover, HG-induced EMT was mediated through SNAIL in tubular epithelial cells (Lee \& Han 2010, Zhao et al. 2017). These data indicate that SNAIL may be an effective target to block EMT in tubular epithelial cells and thereby may be protective against fibrosis. In the current study, we found that SRT1720 administration diminished EMT and SNAIL expressions in vitro and in vivo. Moreover, HIF1A or GLUT1 siRNA inhibited HG-induced EMT and SNAIL expression in HK-2 cells.

Previous studies have shown that lack of SIRT1 in $\beta$-cells leads to impaired glucose sensing and insulin secretion (Ramsey et al. 2008, Luu et al. 2013). SRT3025, an SIRT1 activator, ameliorated hyperglycemia, augmented plasma insulin concentrations, increased pancreatic islet beta cell mass and elevated hepatic beta cell growth factor beta-trophin expression in $\mathrm{db} / \mathrm{db}$ mice (Gilbert et al. 2015). In Zucker fa/fa rats, SRT1720 improved glucose homeostasis and insulin sensitivity (Milne et al. 2007). In our study, SRT1720 reduced the blood glucose levels in $\mathrm{db} / \mathrm{db}$ mice. Therefore, SRT1720 is likely involved in glucose homeostasis via SIRT1 induction in diabetic mice, suggesting that SRT1720 prevents diabetes-associated kidney injury partly through reduction of blood glucose levels.

In conclusion, the results from our in vivo and in vitro studies demonstrate that SRT1720 plays a protective role against DN by suppressing renal fibrosis. Moreover, our findings support the notion that SRT1720 reduces renal fibrosis via SIRT1/HIF1A/GLUT1/SNAIL pathway. Therefore, we speculate that SIRT1 can be a key target during $\mathrm{DN}$ treatment.

\section{Declaration of interest}

The authors declare that there is no conflict of interest that could be perceived as prejudicing the impartiality of the research reported.

\section{Funding}

This study was supported by grants from the National Natural Science Foundation of China (No. 81370825; 81470966), China Postdoctoral Science Foundation (No. 2014M561199) and Hebei Human Resources and Social Security Department Project (No. A2017003080).

\section{Author contribution statement}

$\mathrm{W} \mathrm{H}, \mathrm{YS}$ and $\mathrm{H} \mathrm{D}$ contributed to the design, analysis and interpretation of data. Z Y, W H, L M, M W, N C and C D performed the study. C W performed tissue sectioning, staining, data acquisition and data analysis. $\mathrm{W} \mathrm{H}, \mathrm{Z} Y$ and Y S analysed the data, wrote the manuscript and revised the manuscript. https://joe.bioscientifica.com https://doi.org/10.1530/JOE-18-0536
(C) 2019 Society for Endocrinology Published by Bioscientifica Ltd. Printed in Great Britain 


\section{References}

Bae JU, Lee SJ, Seo KW, Kim YH, Park SY, Bae SS \& Kim CD 2013 SIRT1 attenuates neointima formation by inhibiting HIF-1alpha expression in neointimal lesion of a murine wire-injured femoral artery. International Journal of Cardiology 168 4393-4396. (https://doi. org/10.1016/j.ijcard.2013.05.044)

Du R, Xia L, Ning X, Liu L, Sun W, Huang C, Wang H \& Sun S 2014 Hypoxia-induced Bmi1 promotes renal tubular epithelial cellmesenchymal transition and renal fibrosis via PI3K/Akt signal. Molecular Biology of the Cell 25 2650-2659. (https://doi.org/10.1091/ mbc.E14-01-0044)

Fan H, Yang HC, You L, Wang YY, He WJ \& Hao CM 2013 The histone deacetylase, SIRT1, contributes to the resistance of young mice to ischemia/reperfusion-induced acute kidney injury. Kidney International 83 404-413. (https://doi.org/10.1038/ki.2012.394)

Gilbert RE \& Cooper ME 1999 The tubulointerstitium in progressive diabetic kidney disease: more than an aftermath of glomerular injury? Kidney International 56 1627-1637. (https://doi.org/10.1046/j.15231755.1999.00721.x)

Gilbert RE, Thai K, Advani SL, Cummins CL, Kepecs DM, Schroer SA, Woo M \& Zhang Y 2015 SIRT1 activation ameliorates hyperglycaemia by inducing a torpor-like state in an obese mouse model of type 2 diabetes. Diabetologia 58 819-827. (https://doi.org/10.1007/s00125014-3485-4)

Gorin Y, Block K, Hernandez J, Bhandari B, Wagner B, Barnes JL \& Abboud HE 2005 Nox4 NAD(P)H oxidase mediates hypertrophy and fibronectin expression in the diabetic kidney. Journal of Biological Chemistry 280 39616-39626. (https://doi.org/10.1074/jbc. M502412200)

Grande MT, Sanchez-Laorden B, Lopez-Blau C, De Frutos CA, Boutet A, Arevalo M, Rowe RG, Weiss SJ, Lopez-Novoa JM \& Nieto MA 2015 Snail1-induced partial epithelial-to-mesenchymal transition drives renal fibrosis in mice and can be targeted to reverse established disease. Nature Medicine 21 989-997. (https://doi.org/10.1038/ nm.3901)

Higgins DF, Kimura K, Bernhardt WM, Shrimanker N, Akai Y, Hohenstein B, Saito Y, Johnson RS, Kretzler M, Cohen CD et al. 2007 Hypoxia promotes fibrogenesis in vivo via HIF-1 stimulation of epithelial-to-mesenchymal transition. Journal of Clinical Investigation 117 3810-3820. (https://doi.org/10.1172/JCI30487)

Hong Q, Zhang L, Das B, Li Z, Liu B, Cai G, Chen X, Chuang PY, He JC \& Lee K 2018 Increased podocyte Sirtuin-1 function attenuates diabetic kidney injury. Kidney International 93 1330-1343. (https://doi. org/10.1016/j.kint.2017.12.008)

Isoe T, Makino Y, Mizumoto K, Sakagami H, Fujita Y, Honjo J, Takiyama Y, Itoh H \& Haneda M 2010 High glucose activates HIF-1-mediated signal transduction in glomerular mesangial cells through a carbohydrate response element binding protein. Kidney International 78 48-59. (https://doi.org/10.1038/ki.2010.99)

Jha JC, Gray SP, Barit D, Okabe J, El-Osta A, Namikoshi T, ThallasBonke V, Wingler K, Szyndralewiez C, Heitz F et al. 2014 Genetic targeting or pharmacologic inhibition of NADPH oxidase nox 4 provides renoprotection in long-term diabetic nephropathy. Journal of the American Society of Nephrology 25 1237-1254. (https://doi. org/10.1681/ASN.2013070810)

Kim MY, Lim JH, Youn HH, Hong YA, Yang KS, Park HS, Chung S, Ko SH, Shin SJ, Choi BS et al. 2013 Resveratrol prevents renal lipotoxicity and inhibits mesangial cell glucotoxicity in a manner dependent on the AMPK-SIRT1-PGC1alpha axis in db/db mice. Diabetologia 56 204-217. (https://doi.org/10.1007/s00125-012-2747-2)

Kimura K, Iwano M, Higgins DF, Yamaguchi Y, Nakatani K, Harada K, Kubo A, Akai Y, Rankin EB, Neilson EG et al. 2008 Stable expression of HIF-1alpha in tubular epithelial cells promotes interstitial fibrosis. American Journal of Physiology: Renal Physiology 295 F1023-F1029. (https://doi.org/10.1152/ajprenal.90209.2008)
Kitada M, Kume S, Imaizumi N \& Koya D 2011 Resveratrol improves oxidative stress and protects against diabetic nephropathy through normalization of Mn-SOD dysfunction in AMPK/SIRT1-independent pathway. Diabetes 60 634-643. (https://doi.org/10.2337/db10-0386)

Kulkarni SR, Soroka CJ, Hagey LR \& Boyer JL 2016 Sirtuin 1 activation alleviates cholestatic liver injury in a cholic acid-fed mouse model of cholestasis. Hepatology 64 2151-2164. (https://doi.org/10.1002/ hep.28826)

Lan HY 2011 Diverse roles of TGF-beta/Smads in renal fibrosis and inflammation. International Journal of Biological Sciences 7 1056-1067. (https://doi.org/10.7150/ijbs.7.1056)

Lee YJ \& Han HJ 2010 Troglitazone ameliorates high glucose-induced EMT and dysfunction of SGLTs through PI3K/Akt, GSK-3beta, Snail1, and beta-catenin in renal proximal tubule cells. American Journal of Physiology. Renal Physiology 298 F1263-F1275. (https://doi. org/10.1152/ajprenal.00475.2009)

Li J, Qu X, Ricardo SD, Bertram JF \& Nikolic-Paterson DJ 2010 Resveratrol inhibits renal fibrosis in the obstructed kidney: potential role in deacetylation of Smad3. American Journal of Pathology 177 1065-1071. (https://doi.org/10.2353/ajpath.2010.090923)

Li X, Cai W, Lee K, Liu B, Deng Y, Chen Y, Zhang X, He JC \& Zhong Y $2017 a$ Puerarin attenuates diabetic kidney injury through the suppression of NOX4 expression in podocytes. Scientific Reports $\mathbf{7}$ 14603. (https://doi.org/10.1038/s41598-017-14906-8)

Li X, Li J, Wang L, Li A, Qiu Z, Qi LW, Kou J, Liu K, Liu B \& Huang F 2016 The role of metformin and resveratrol in the prevention of hypoxiainducible factor 1alpha accumulation and fibrosis in hypoxic adipose tissue. British Journal of Pharmacology 173 2001-2015. (https://doi. org/10.1111/bph.13493)

Li Z, Bridges B, Olson J \& Weinman SA 2017b The interaction between acetylation and serine-574 phosphorylation regulates the apoptotic function of FOXO3. Oncogene 36 1887-1898. (https://doi. org/10.1038/onc.2016.359)

Lim JH, Lee YM, Chun YS, Chen J, Kim JE \& Park JW 2010 Sirtuin 1 modulates cellular responses to hypoxia by deacetylating hypoxiainducible factor 1alpha. Molecular Cell 38 864-878. (https://doi. org/10.1016/j.molcel.2010.05.023)

Liu R, Zhong Y, Li X, Chen H, Jim B, Zhou MM, Chuang PY \& He JC 2014 Role of transcription factor acetylation in diabetic kidney disease. Diabetes 63 2440-2453. (https://doi.org/10.2337/db13-1810)

Liu Y 2004 Epithelial to mesenchymal transition in renal fibrogenesis: pathologic significance, molecular mechanism, and therapeutic intervention. Journal of the American Society of Nephrology 15 1-12. (https://doi.org/10.1097/01.ASN.0000106015.29070.E7)

Lo CS, Shi Y, Chenier I, Ghosh A, Wu CH, Cailhier JF, Ethier J, Lattouf JB, Filep JG, Ingelfinger JR et al. 2017 Heterogeneous nuclear ribonucleoprotein F stimulates Sirtuin-1 gene expression and attenuates nephropathy progression in diabetic mice. Diabetes 66 1964-1978. (https://doi.org/10.2337/db16-1588)

Luu L, Dai FF, Prentice KJ, Huang X, Hardy AB, Hansen JB, Liu Y, Joseph JW \& Wheeler MB 2013 The loss of Sirt1 in mouse pancreatic beta cells impairs insulin secretion by disrupting glucose sensing. Diabetologia 56 2010-2020. (https://doi.org/10.1007/s00125-013-2946-5)

Milne JC, Lambert PD, Schenk S, Carney DP, Smith JJ, Gagne DJ, Jin L, Boss O, Perni RB, Vu CB et al. 2007 Small molecule activators of SIRT1 as therapeutics for the treatment of type 2 diabetes. Nature $\mathbf{4 5 0}$ 712-716. (https://doi.org/10.1038/nature06261)

Mogyorósi A \& Ziyadeh FN 1999 GLUT1 and TGF-beta: the link between hyperglycaemia and diabetic nephropathy. Nephrology, Dialysis, Transplantation 14 2827-2829. (https://doi.org/10.1093/ ndt/14.12.2827)

Moynihan KA, Grimm AA, Plueger MM, Bernal-Mizrachi E, Ford E, Cras-Meneur C, Permutt MA \& Imai S 2005 Increased dosage of mammalian Sir2 in pancreatic beta cells enhances glucose-stimulated insulin secretion in mice. Cell Metabolism 2 105-117. (https://doi. org/10.1016/j.cmet.2005.07.001) 
Navarro-Gonzalez JF, Mora-Fernandez C, Muros de Fuentes M \& Garcia-Perez J 2011 Inflammatory molecules and pathways in the pathogenesis of diabetic nephropathy. Nature Reviews: Nephrology 7 327-340. (https://doi.org/10.1038/nrneph.2011.51)

Nayak BK, Shanmugasundaram K, Friedrichs WE, Cavaglierii RC, Patel M, Barnes J \& Block K 2016 HIF-1 mediates renal fibrosis in OVE26 Type 1 diabetic mice. Diabetes 65 1387-1397. (https://doi.org/10.2337/ db15-0519)

Okada H, Kikuta T, Kobayashi T, Inoue T, Kanno Y, Takigawa M, Sugaya T, Kopp JB \& Suzuki H 2005 Connective tissue growth factor expressed in tubular epithelium plays a pivotal role in renal fibrogenesis. Journal of the American Society of Nephrology 16 133-143. (https://doi. org/10.1681/ASN.2004040339)

Ramsey KM, Mills KF, Satoh A \& Imai S 2008 Age-associated loss of Sirt1-mediated enhancement of glucose-stimulated insulin secretion in beta cell-specific Sirt1-overexpressing (BESTO) mice. Aging Cell 7 78-88. (https://doi.org/10.1111/j.1474-9726.2007.00355.x)

Ren Y, Du C, Shi Y, Wei J, Wu H \& Cui H 2017 The Sirt1 activator, SRT1720, attenuates renal fibrosis by inhibiting CTGF and oxidative stress. International Journal of Molecular Medicine 39 1317-1324. (https://doi.org/10.3892/ijmm.2017.2931)

Ricci C, Iacobini C, Oddi G, Amadio L, Menini S, Rastaldi MP, Frasheri A, Pricci F, Pugliese F \& Pugliese G 2006 Role of TGF-beta/GLUT1 axis in susceptibility vs resistance to diabetic glomerulopathy in the Milan rat model. Nephrology, Dialysis, Transplantation 21 1514-1524. (https://doi.org/10.1093/ndt/gfk089)

Rosenberger C, Khamaisi M, Abassi Z, Shilo V, Weksler-Zangen S, Goldfarb M, Shina A, Zibertrest F, Eckardt KU, Rosen S et al. 2008 Adaptation to hypoxia in the diabetic rat kidney. Kidney International 73 34-42. (https://doi.org/10.1038/sj.ki.5002567)

Schmid H, Boucherot A, Yasuda Y, Henger A, Brunner B, Eichinger F, Nitsche A, Kiss E, Bleich M, Grone HJ et al. 2006 Modular activation of nuclear factor-kappaB transcriptional programs in human diabetic nephropathy. Diabetes 55 2993-3003. (https://doi.org/10.2337/db060477)

Singh DK, Winocour P \& Farrington K 2008 Mechanisms of disease: the hypoxic tubular hypothesis of diabetic nephropathy. Nature Clinical Practice: Nephrology 4 216-226. (https://doi.org/10.1038/ncpneph0757)
Sun S, Ning X, Zhang Y, Lu Y, Nie Y, Han S, Liu L, Du R, Xia L, He L et al. 2009 Hypoxia-inducible factor-1alpha induces Twist expression in tubular epithelial cells subjected to hypoxia, leading to epithelial-tomesenchymal transition. Kidney International 75 1278-1287. (https:// doi.org/10.1038/ki.2009.62)

Sun Y, Peng R, Peng H, Liu H, Wen L, Wu T, Yi H, Li A \& Zhang Z 2016 miR-451 suppresses the NF-kappaB-mediated proinflammatory molecules expression through inhibiting LMP7 in diabetic nephropathy. Molecular and Cellular Endocrinology 433 75-86. (https:// doi.org/10.1016/j.mce.2016.06.004)

Takiyama Y, Harumi T, Watanabe J, Fujita Y, Honjo J, Shimizu N, Makino Y \& Haneda M 2011 Tubular injury in a rat model of type 2 diabetes is prevented by metformin: a possible role of HIF-1alpha expression and oxygen metabolism. Diabetes 60 981-992. (https:// doi.org/10.2337/db10-0655)

Wang RH, Kim HS, Xiao C, Xu X, Gavrilova O \& Deng CX 2011 Hepatic Sirt1 deficiency in mice impairs mTorc2/Akt signaling and results in hyperglycemia, oxidative damage, and insulin resistance. Journal of Clinical Investigation 121 4477-4490. (https://doi.org/10.1172/ JCI46243)

Wang S, Denichilo M, Brubake C \& Hirschberg R 2001 Connective tissue growth factor in tubulointerstitial injury of diabetic nephropathy. Kidney International 60 96-105. (https://doi.org/10.1046/j.15231755.2001.00776.x)

Yuan Y, Chen Y, Zhang P, Huang S, Zhu C, Ding G, Liu B, Yang T \& Zhang A 2012 Mitochondrial dysfunction accounts for aldosteroneinduced epithelial-to-mesenchymal transition of renal proximal tubular epithelial cells. Free Radical Biology and Medicine 53 30-43. (https://doi.org/10.1016/j.freeradbiomed.2012.03.015)

Zhao HJ, Wang S, Cheng H, Zhang MZ, Takahashi T, Fogo AB, Breyer MD \& Harris RC 2006 Endothelial nitric oxide synthase deficiency produces accelerated nephropathy in diabetic mice. Journal of the American Society of Nephrology 17 2664-2669. (https://doi. org/10.1681/ASN.2006070798)

Zhao Y, Yin Z, Li H, Fan J, Yang S, Chen C \& Wang DW 2017 MiR30c protects diabetic nephropathy by suppressing epithelial-tomesenchymal transition in db/db mice. Aging Cell 16 387-400. (https://doi.org/10.1111/acel.12563)

Received in final form 9 February 2019

Accepted 22 February 2019

Accepted Preprint published online 22 February 2019 https://joe.bioscientifica.com https://doi.org/10.1530/JOE-18-0536 (c) 2019 Society for Endocrinology Published by Bioscientifica Ltd. Printed in Great Britain 